J. Clin. Chem. Clin. Biochem.

Vol. 18, 1980, pp. 49-52

\title{
Kinetic Determination of Serum Glucose by Use of the Hexokinase/Glucose-6-phosphate Dehydro- genase Method
}

By R. Deeg, W. Kraemer and J. Ziegenhorn

Boehringer Mannheim GmbH, -Biochemica Wert Tutzing, Forschungszentrum, D-8132 Tutzing

(Received May 12/August 20, 1979)

Summary: We have developed a kinetic fixed-time approach for the quantitative determination of serum glucose by use of the hexokinase/glucose-6-phosphate dehydrogenase method. To achieve a large measuring range, we have apparently increased the Michaelis constant of glucose-6-phosphate dehydrogenase through addition of the competitive inhibitor ATP. By this means, serum samples with glucose concentrations up to $55.5 \mathrm{mmol} / \mathrm{l}$ could be analyzed without pre-dilution. The method has been adapted to the ENI GEMSAEC analyzer and to the LKB 2086 Mark II analyzer. It yielded satisfactory results with regard to precision. A comparison of the kinetic procedure with the manual end-point method showed good agreement. No interferences from hemoglobin, bilirubin, or lipemia have been observed.

\section{Kinetische Bestimmung von Glucose im Serum mit der Hexokinase/Glucose-6-phosphat-Dehydrogenase-Methode}

Zusammenfassung: Wir haben für die quantitative Bestimmung der Serumglucose nach der Hexokinase/Glucose-6phosphat-Dehydrogenase-Methode ein kinetisches "fixed-time"-Verfahren entwickelt. Um für das Verfahren einen großen Meßbereich zu erhalten, wurde die Michaelis-Konstante der Glucose-6-phosphat-Dehydrogenase durch Zugabe des kompetitiven Inhibitors ATP scheinbar erhöht. Auf diese Weise konnten Serumproben mit einer Glucosekonzentration bis $55,5 \mathrm{mmol} / \mathrm{l}$ ohne Vorverdünnung bestimmt werden. Die Methode wurde auf die Analysenautomaten ENI GEMSAEC und LKB 2086 Mark II adaptiert. Die Untersuchung der Präzision lieferte zufriedenstellende Ergebnisse. Ein Vergleich der kinetischen Methode mit der manuellen Endwert-Methode zeigte gute Übereinstimmung. Störungen durch Hämoglobin, Bilirubin oder Lipämie traten nicht auf.

\section{Introduction}

Due to its specificity and its insensitivity to interference, the hexokinase/glucose-6-phosphate dehydrogenase method has found worldwide acceptance as a reference method for the determination of glucose in body fluids (1). It is based on the following reaction sequence in which the second step is responsible for the high specifi: city of the assay (2).

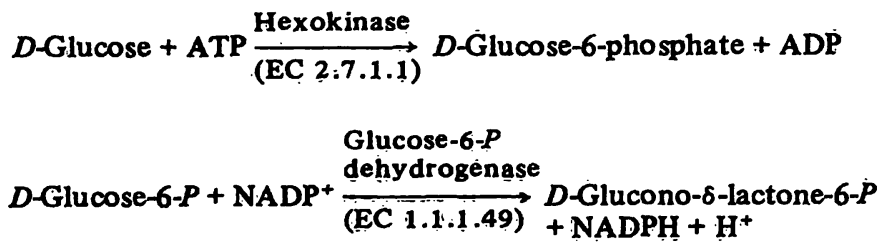

The assay is commonly carried out as an end-point procedure $(1,2)$. To improve the convenience of the method for the automated clinical laboratory, we studied the feasibility of a kinetic fixed-time approach which allows reduction of the reaction time and omission of the technically elaborate determination of the initial absorbance (3).

Because of the low Michaelis constant of glucose-6phosphate dehydrogenase with respect to glucose-6phosphate (4), the kinetic glucose assay using this enzyme and hexokinase is not, at first sight, suited for the determination of high glucose concentrations (3). However, following the theory of Michaelis and Menten, this situation can be improved by the addition of a competitive inhibitor which apparently increases the $K_{\mathrm{m}}$ - 
value of the enzyme $(3,5)$. Therefore, we first looked for a suitable compound which competitively inhibits glucose-6-phosphate dehydrogenase with respect to glucose-6-phosphate. The kinetic glucose assay was then performed in the presence of this inhibitor, using an ENI GEMSAEC analyzer and an LKB 2086 Mark II analyzer.

\section{Materials and Methods}

\section{Apparatus}

The automated methods were performed using an ENI GEMSAEC centrifugal analyzer (Electro-Nucleonics, 368 Passaic Ave., Fairfield, N.J. 07006) and a LKB 2086 Mark II kinetic analyzer (LKB Clinicon AB, S-16126 Bromma, Sweden). For the LKB 2086 Mark II method, samples and reagents were dispensed with an LKB 2075 diluter. Manual assays were done with a Model $1101 \mathrm{M}$ spectrum line photometer which was connected with a Model 6511 recorder (Eppendorf Gerätebau Netheler \& Hinz GmbH, D-2000 Hamburg 63).

\section{Reagents}

Hexokinase test kit "Gluco-quant", cat. No. 245178 ; ATP cat. No. 127 531; $\beta$ - $D$-glucose-6-phosphate, cat. No. 105 333; NADP, cat. No. 128 040; glucose standards "Preciset Glucoșe", cat. No. 125 563, and glucose-6-phosphate dehydrogenase from Leuconostoc mesenteroides, cat. No. 165 883, were all from Boehringer Mannheim, P.O. Box 51, D-6800 Mannheim 31, Germany. Dglucose and bilirubin were from E. Merck, D-6100 Darmstadt, Germany. According to the manufacturer's instructions reagent 1 of the test kit was reconstituted to $200 \mathrm{ml}$ with distilled water giving a concentration of $70 \mathrm{mmol} / \mathrm{l}$ phosphate buffer ( $\mathrm{pH} 7.7$ ), $1.3 \mathrm{mmol} / 1 \mathrm{NADP}, 1.3 \mathrm{mmol} / \mathrm{ATP}$ and $4 \mathrm{mmol} / 1 \mathrm{MgSO}_{4}$. Reagent 2 contained $\geqslant 100 \mathrm{kU} / 1$ hexokinase and $\geqslant 180 \mathrm{kU} / 1$ glucose-6-phosphate dehydrogenase.

For the GEMSAEC method, a single reagent was prepared by adding $2 \mathrm{ml}$ of reagent 2 and $1.80 \mathrm{~g}(2.97 \mathrm{mmol})$ of ATP to $200 \mathrm{ml}$ of reagent 1 solution. For the LKB 2086 Mark II method, $3.15 \mathrm{~g}$ ( $5.20 \mathrm{mmol})$ of ATP was added to $200 \mathrm{ml}$ of reagent 1 solution. The starting reagent was obtained by mixing $20 \mathrm{ml}$ of this solution with $2 \mathrm{ml}$ of reagent 2 . For the inhibition studies, an assay mixture was prepared by adding $20 \mathrm{U}$ of glucose- 6 phosphate dehydrogenase and varying ATP concentrations to $200 \mathrm{ml}$ of reagent 1 solution. The reagents were stable for at least one day at $25^{\circ} \mathrm{C}$.

Samples

The sera used in the experiments were from patients. High glucose concentrations were obtained by adding various amounts of glucose to a human serum pool. Control sera were all from Boehringer Mannheim.

\section{Procedures}

\section{GEMSAEC}

The adjustment of the GEMSAEC system was as follows: Rotoloader: sample-switch, B; blank-switch, water; sample volume, $5 \mu \mathrm{l}$; flush volume, $150 \mu \mathrm{l}$ (physiological saline diluent); reagent volume, $500 \mu 1$. The reagent was pipetted into well $\bar{C}$ of the transfer disk.

Analyzer: reaction temperature, $25^{\circ} \mathrm{C}$; wavelength, 340 ṇm; filter range, $335-385 \mathrm{~nm}$.

Control: reaction mode, rate; running mode, auto; initial reading (IR), $25 \mathrm{~s}$; reading interval (RI), $10 \mathrm{~s}$; number of readings (NR), 5 .

The sample ring was loaded in the following sequence: position 1 , distilled water; position 2, standard ( $5.55 \mathrm{mmol} / 1$ ); positions $3-16$, control sera and patient's samples. The caloulation of the results was performed with the computer program $\mathrm{TC}=5$ which is designed for routine kinetic fixed-time analysis (ElectroNucleonics International LTD, Adriaan van Bergenstraat 202208, 4811 SW Breda, Holland).

\section{LKB 2086 Mark II}

The LKB-system was set up as follows:

Analyzer: temperature, $25^{\circ} \mathrm{C}$; wavelength, $340 \mathrm{~nm}$, light setting, $0.7 \mathrm{~A}$; reaction course, increase; dispensing volume, $100 \mu l$; injection position, 2; delay, on; measuring range, 0.2 ; cuvette, $10 \mathrm{~mm}$, timer, $5 \mathrm{~min}$.; feed-in-switch, timer.

Data Processor: program type, fixed time; delay, yes; time of first measurement, $0 \mathrm{~s}$; time of second measurement, $30 \mathrm{~s}$; regression, linear; number of standards, 3 ; concentration of standards, $5.55 \mathrm{mmol} / \mathrm{l}$; deviation for deleting standard samples, $10 \%$.

$10 \mu \mathrm{l}$ of calibration standard or sample and $900 \mu \mathrm{l}$ of reagent 1 solution were dispensed into the $10 \mathrm{~mm}$ disposables cuvettes.

\section{Other procedures}

The manual assays were carried out in $1 \mathrm{~cm}$ cuvettes at $25^{\circ} \mathrm{C}$ and at $\mathrm{Hg} 365 \mathrm{~nm}$. For measuring the activity of glucose-6phosphate dehydrogenase in the presence of varying ATP concentrations, $2 \mathrm{ml}$ of the assay mixture and $20 \mu$ lof glucose6-phosphate-solution were used. The reaction was started by addition of glucose-6-phosphate. For determining the type of inhibition, the initial rates were measured and their reciprocal values plotted vs. the reciprocal substrate concentrations.

\section{Results and Discussion}

At present, in commercially available test kits for the determination of glucose according to the hexokinase end-point procedure, the glucose-6-phosphate dehydrogenase from Leuconostoc mesenteroides is commonly used. This enzyme is known to be inhibited by pyridoxalphosphate (6), ATP and acyl-CoA derivatives (7). Stimulated by the fact that ATP is already employed as lowpriced and stable competitive inhibitor for the kinetic determination of serum triglycerides (8) we preferably looked into the suitability of that substance for the kinetic glucose assay.

To determine the type of inhibition of glucose-6-phosphate dehydrogenase by ATP, we first studied the kinetics of this enzymatic reaction in the presence of increasing amounts of ATP. The results of the experiments are shown in figure 1 , using a Lineweaver-Burk plot (9). As indicated by the common point of intersection of the curves on the $1 / v$ axis, ATP exerts a competitive type of inhibition with respect to glucose-6phosphate.

This finding suggested to us that, for the kinetic glucose assay, the $K_{\mathrm{m}}$-value of glucose-6-phosphate dehydrogenase could be increased by simply elevating the ATP concentration usually employed for the end-point method. An ATP concentration of about $17 \mathrm{mmol} / \mathrm{l}$ in the reaction mixture was calculated to cause the required shift of the Michaelis constant (3). Figure 2 demonstrates that under these conditions, after a short lag phase, the overall reaction of the glucose assay followed pseudo-first-order kinetics with respect to glucose concentration. This, however, is known to be the basic requirement for a kinetic substrate determination by use of the fixed-time procedure (3): 


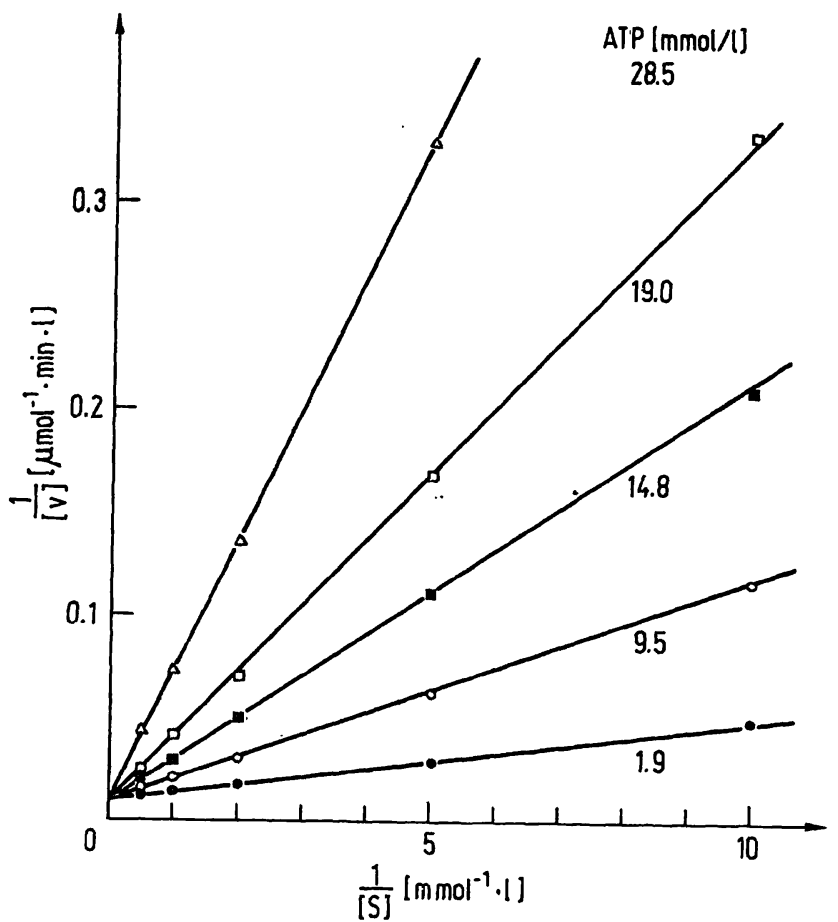

Fig. 1. Inhibition of glucose-6-phosphate dehydrogenase by ATP.

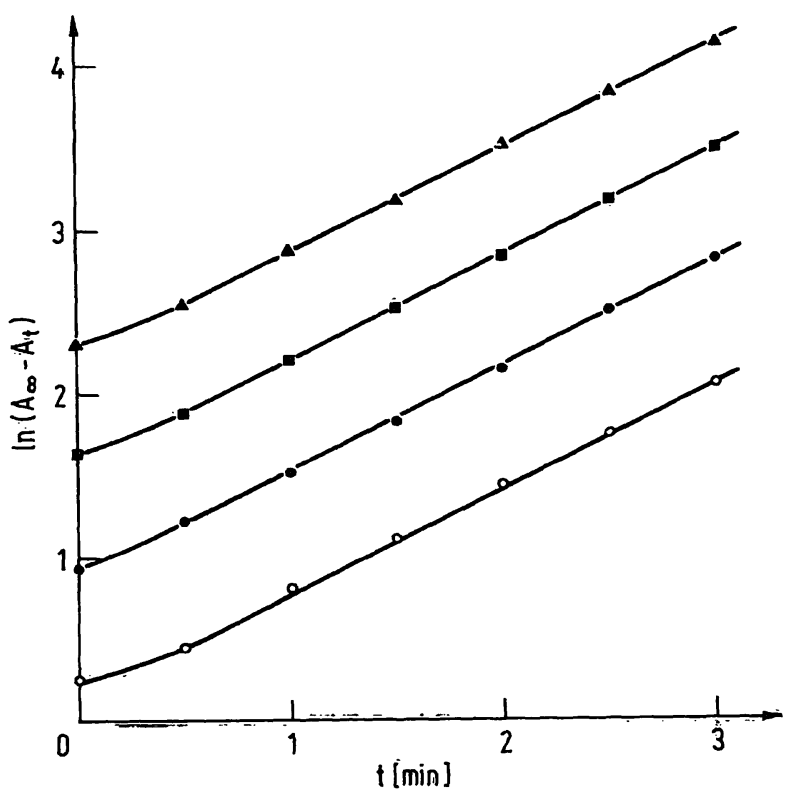

Fig. 2. Time course of reaction. A absorbañcè at time $t, A_{\infty}$ absoibance after completion of reaction. Samples: glucose standards $\triangle \sim 2.78 \mathrm{mmol} / \mathrm{l}, \longrightarrow 5.55 \mathrm{mmol} / \mathrm{l}$, $\rightarrow 11.10 \mathrm{mmol} / 1,0 \longrightarrow 022.20 \mathrm{mmol} / \mathrm{l}$. The response curves were recorded at $\mathrm{Hg} 365 \mathrm{~nm}$ using the GEMSAEC reạgent.

\section{Measuring range and sensitivity}

We assayed dilutions of a stock solution of high purity $D$. glucose giving concentrations between 2.78 and $\mathbf{5 5 . 5}$ mmol/l. Figure 3 shows the results obtained with the GEMSAEC method. A straight line relationship was found

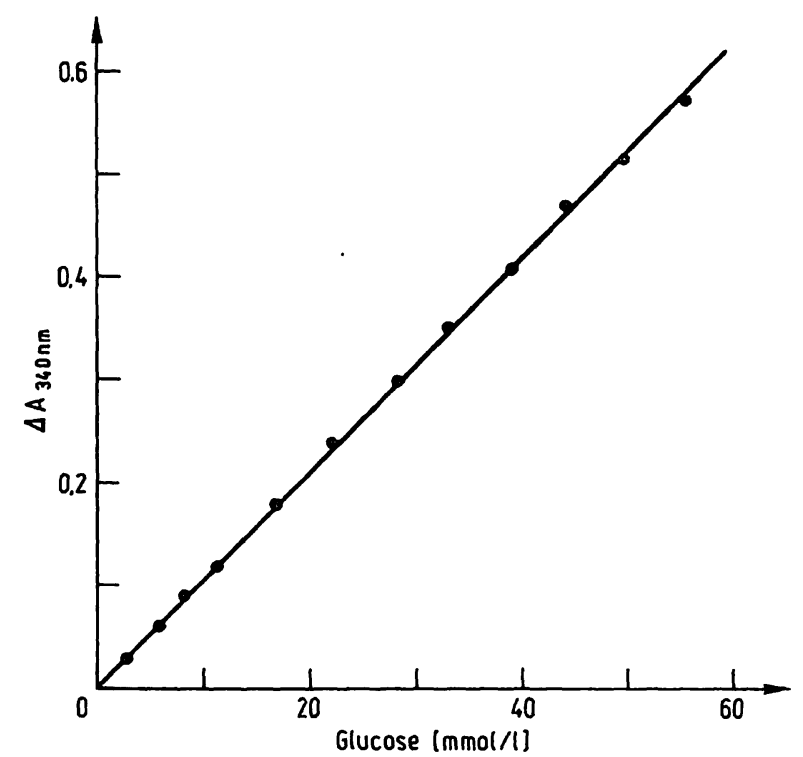

Fig. 3. Fixed-time absorbance change as a function of glucose concentration, measured with the GEMSAEC.

to exist between the fixed-time absorbance changes and the respective glucose concentrations. Furthermore, the figure demonstrates that the sensitivity of the assay was sufficiently high in the normal range of glucose. With the LKB 2086 Mark II method, the measuring range was found to extend up to $44.4 \mathrm{mmol} / \mathrm{l}$ glucose.

\section{Precision}

Table 1 lists the within-run precision of the present method. The data were obtained by simultaneous analysis of aliquots of calibration standard, normal and supranormal human sera. Day-to-day precision was studied for six days by repeated analysis of the control serum Precinorm U (Boehringer Mannheim). Satisfactory results were obtained with both methods; GEMSAEC: mean $=5.45$ $\mathrm{mmol} / \mathrm{l}, \mathrm{CV}=2.5 \%$; LKB 2086 Mark II: Mean $=5.38$ $\mathrm{mmol} / \mathrm{l}, \mathrm{CV}=3.4 \%$.

Tab. 1. Within-run precision of present method.

\begin{tabular}{llllll}
\hline \multirow{2}{*}{ Method } & Sample & No. tests $\begin{array}{l}\text { Glucose } \\
\text { (mmol/l) }\end{array}$ & CV (\%) \\
& & & \multicolumn{1}{c}{$\bar{x}$} & $\pm \mathrm{s}$ & \\
\hline GEM- & Standard & 14 & 5.57 & 0.04 & 0.72 \\
SAEC & Serum & 14 & 5.22 & 0.05 & 0.96 \\
& Serum & 14 & 7.53 & 0.06 & 0.80 \\
& Serum & 14 & 11.98 & 0.08 & 0.67 \\
& Serum & 14 & 29.82 & 0.21 & 0.70 \\
LKB & Standard & 20 & 5.53 & 0.05 & 0.90 \\
2086 & Serum & 20 & 5.43 & 0.05 & 0.92 \\
Mark II & Serum & 20 & 8.73 & 0.09 & 1.03 \\
& Serum & 20 & 12.98 & 0.15 & 1.16 \\
& Serum & 20 & 23.41 & 0.32 & 1.37 \\
\hline
\end{tabular}




\section{Accuracy}

The correlation of the automated methods with the manual hexokinase end-point method was tested on 59 native human sera.

The results obtained with the GEMSAEC method are illustrated in figure 4. The calculated regression parameters indicate the good accuracy of the method. Equally satisfactory results were obtained with the LKB 2086 Mark II method: $y=0.981 x+0.578$, $\mathrm{r}=0.997$.

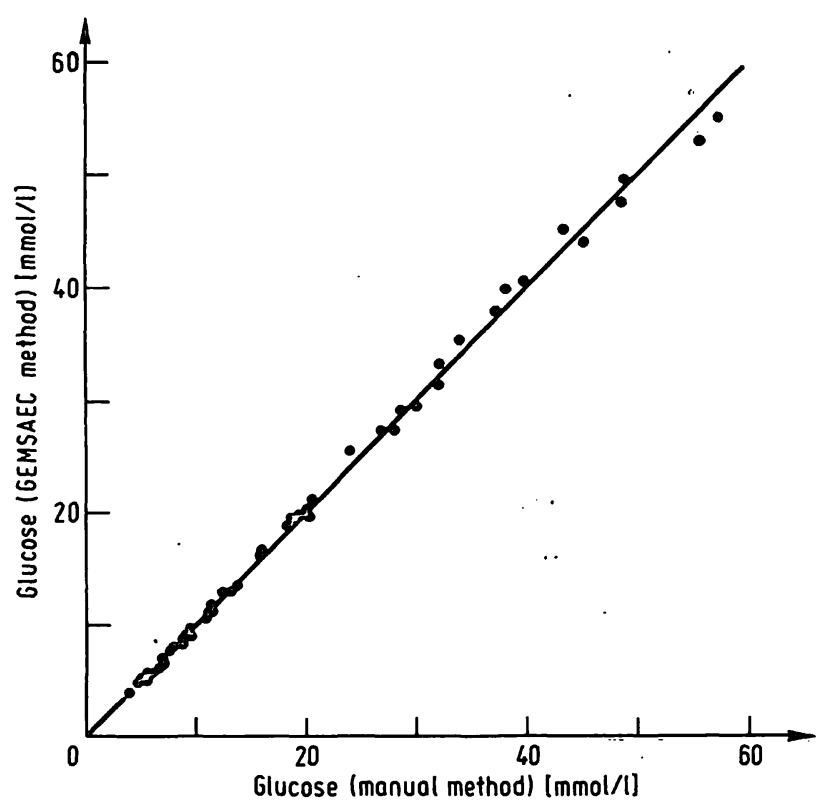

Fig. 4. Comparison of present GEMSAEC method (y) with manual hexokinase method $(x)$ for glucose in native human sera. $n=59, y=0.987 x+0.26, r=0.998$.
Tab. 2. Effect of added bilirubin or hemoglobin on the glucose value of a human serum, as measured by the GEMSAEC method.

\begin{tabular}{lcl}
\hline $\begin{array}{l}\text { Bilirubin added } \\
(\mu \mathrm{mol} / \mathrm{l})\end{array}$ & $\begin{array}{l}\text { Hemoglobin added } \\
(\mu \mathrm{mol} / \mathrm{l})\end{array}$ & $\begin{array}{l}\text { Glucose found* } \\
(\mathrm{mmol} / \mathrm{l})\end{array}$ \\
\hline- & - & 10.32 \\
20 & - & 10.30 \\
80 & - & 10.42 \\
160 & $\overline{-}$ & 10.51 \\
- & 15 & 10.36 \\
- & 60 & 10.52 \\
- & 150 & 10.48 \\
\hline
\end{tabular}

* mean values of triplicate determination

Similar correlations between the kinetic methods and the endpoint method were observed using plasma samples (EDTA, heparin, citrate).

\section{Interferences}

As illustrated in table 2, colored blood components did not interfere with the kinetic method. The samples used in this experiment were taken from a human serum pool and different amounts of bilirubin or hemoglobin were added. Also no interference was observed from lipemia.

\section{Conclusions}

The present study shows that the reference method for the determination of glucose, the hexokinase/glucose6-phosphate dehydrogenase method, can be carried out kinetically over a wide range of glucose concentration if appropriate assay conditions are used. The kinetic approach, however, is especially suited for automated instruments. It allows a short reaction time. Neither analysis of reagent or sample blanks nor determination of initial absorbances is needed.

\section{References}

1. Richterich, R. \& Colombo, J. P. (1978) Klinische Chemie, Theorie, Praxis, Interpretation, 4. Aufl., 304, S. Karger Verlag, Basel, München, Paris, London, New York, Sydney.

2. Bergmeyer, H. U. \& Bernt, E. (1974) in Methods of Enzymatic Analysis (Bergmeyer, H. U., ed.), Vol. 3, 1196-1201, Academic Press, New York, London.

3. Ziegenhorn, J. (1977) in Grundlagen der enzymatischen Analyse (Bergmeyer, H. U., ed.), 81-85, Verlag Chemie, Weinheim, New York.

4. Barman, T. E. (1969), Enzyme Handbook, Vol. 1, 74, Springer Verlag, Berlin, Heidelberg, New York.
5. Müller-Matthesius, R. (1975), this J. 13, 169-170.

6. Milhausen, M. \& Levy, H. R. (1975) Europ. J. Biochem. 50, 453-461.

7. Coe, E. L. \& Hsu, L.-H. (1973), Biochem. Biophys. Res. Commun. 53, 66-69.

8. Ziegenhorn, J. (1975), Clin. Chem. 21, 1627-1629.

9. Michal, G. (1974) in Methods of Enzymatic Analy sis (Bergmeyer, H. U., Ed.), Vol. 1, 144-156, Academic Press, New Yörk, London.
Dr. R. Deeg

Boehringer Mannheim GmbH Biochemica Werk Tutzing Förschungszèntrum

Postfach 120

D-8132 Tutzing 